\title{
STUDY ON FORMATION OF URBAN TISSUE IN BHAKTAPUR IN KATHMANDU VALLEY, NEPAL
}

\author{
Anri Kido ${ }^{1}$, Naohiko Yamamoto ${ }^{2}$, Masaya Masui $^{3}$ and Yasushi Takeuchi ${ }^{4}$ \\ ${ }^{1} H G C$ Architectural Design Firm \\ ${ }^{2}$ Assoc. Prof., Nara Women's University, JAPAN. \\ ${ }^{3}$ Professor, Nara Women's University, JAPAN. \\ ${ }^{4}$ Assoc. Prof., Miyagi University, JAPAN
}

\begin{abstract}
This paper makes a study of street patterns and organization of dwelling units of the historic city of Bhaktapur, a World Heritage Site in Kathmandu Valley. Spatial syntax is used to analyze the street patterns, which shows the western part of the city as structured along its main street while the eastern part more nucleated with squares as centers of the settlement. With this clue that suggests the development phase of Bhaktapur city, the patterns of dwelling clusters of the eastern part are studied. The study taking into account of specific settlement culture of Newars, the traditional inhabitants of the Valley, then makes a typological differentiation of the dwelling clusters that are also related to development phase of the settlement. The paper then studies the location of the shrine of Ganesa —an essential religious feature of the neighborhood. Further, user households of other community facilities, such as pati-the resting place, and hiti-the water fountain, are identified and the respective user community compared with respect to the neighborhood boundaries.
\end{abstract}

Keywords: Bhaktapur, Newars, spatial syntax, urban tissue, community facilities, neighborhood boundary.

\section{Introduction}

This paper focuses on Bhaktapur city located to the east of Kathmandu Valley, and designated as a World Heritage Site, together with Kathmandu and Patan, by UNESCO since 1979. The objective of the paper is to study the urban structure and urban tissue of the town settlement. Firstly, the paper attempts to find out the typology of 'toles"1 - the neighborhood quarters, defined by elements of urban tissue, such as streets, lanes, squares, distribution of urban facilities, plots and dwelling units. The typology is also examined with respect to community boundaries. Secondly, the paper considers daily activities of the residents and facilities such as shrines for daily prayer, water source for housework and public loggias in the streets where people often take rest and have community activities.

*Corresponding author: Anri Kido

HGC Architectural Design Firm, 13-15 Ushijima-cho Toyama-city, Japan, zip 930-0858

Email: kido@hg-c.co.jp

(Received: 2011 Sept 10

Accepted: 2011 Nov 9)
The paper gives particular emphasis on people’s daily activities and spatial structure where such activities take place to illustrate the essential aspects in the formation of the town settlement.

Our field survey covers the area recorded in the cadastral map drawn in 1985 (2042 BS). The survey area includes the whole tract of old Bhaktapur. It is now surrounded by traffic arteries and separated by several entrance gates from newly built up area. Within this extent, we conducted mapping of urban facilities and public spaces between $23^{\text {rd }}$ August and 11 $1^{\text {th }}$ September 2009 as well as between $15^{\text {th }}$ September and $13^{\text {th }}$ October 2010. In the latter period, hearing investigation was also conducted.

\section{Previous Studies}

Formation of urban space in Bhaktapur follows topographical features than the myth of ideal geometric pattern called 'tripurasundari mandala'

JScE Vol. 1, Falgun 2068

Anri Kido 1 


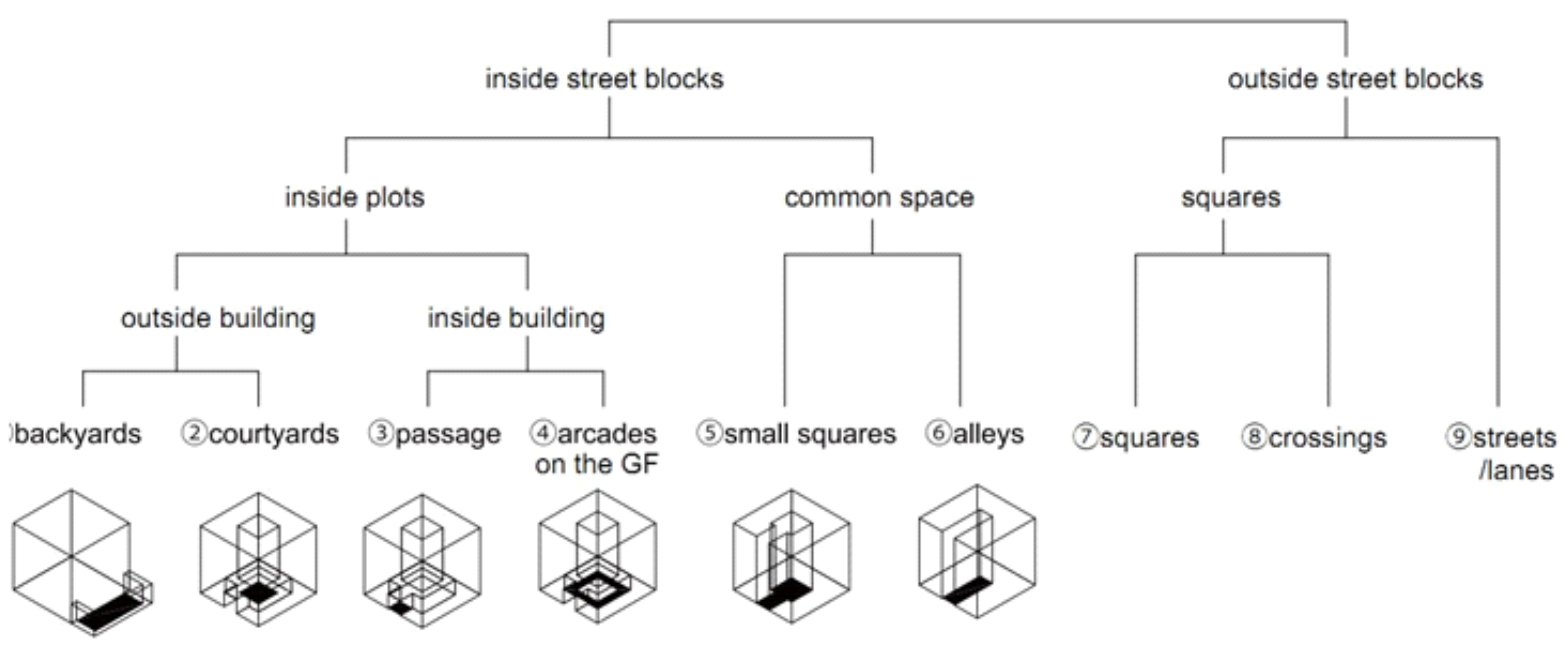

Fig.1. Typology of Public Space, Bhaktapur

(Tiwari, 2009). The town is thought to have begun from the independent hamlets that later merged into an aggregation since 9th century. Comprehensive studies on urban structure of Bhaktapur were conducted by Gutschow since 1975. This study owes several important viewpoints to his research works. The only research on urban tissue of Bhaktapur to the authors' knowledge is Scheibler (1988). Yet it is still limited to a case study and does not present a structural understanding of the city. Pant's studies (2000, 2001) are important research works on the towns of Kathmandu Valley. He explains formation of community units on the basis of the development

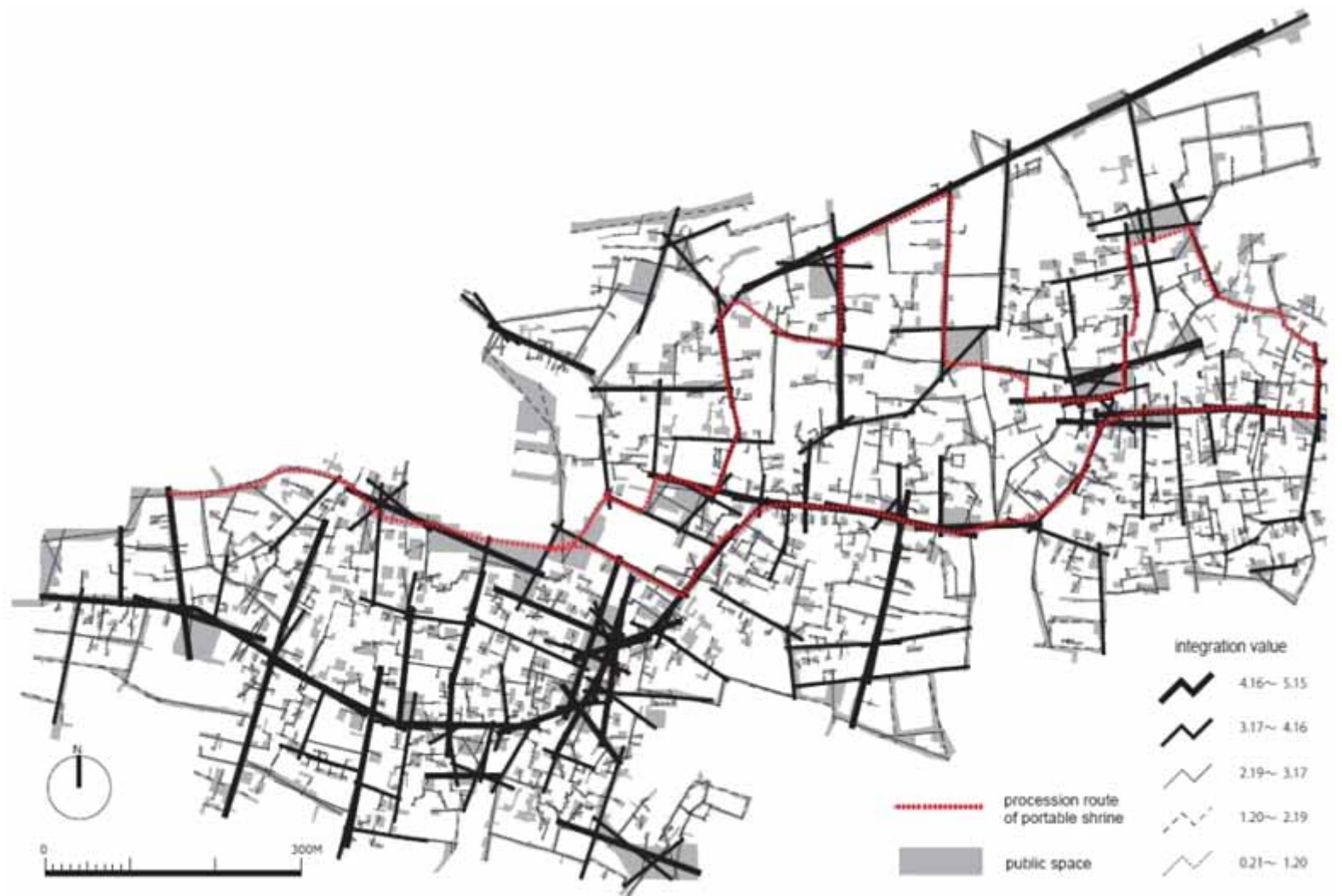

Fig.2. The result of axial line analysis and procession route of a portable shrine 


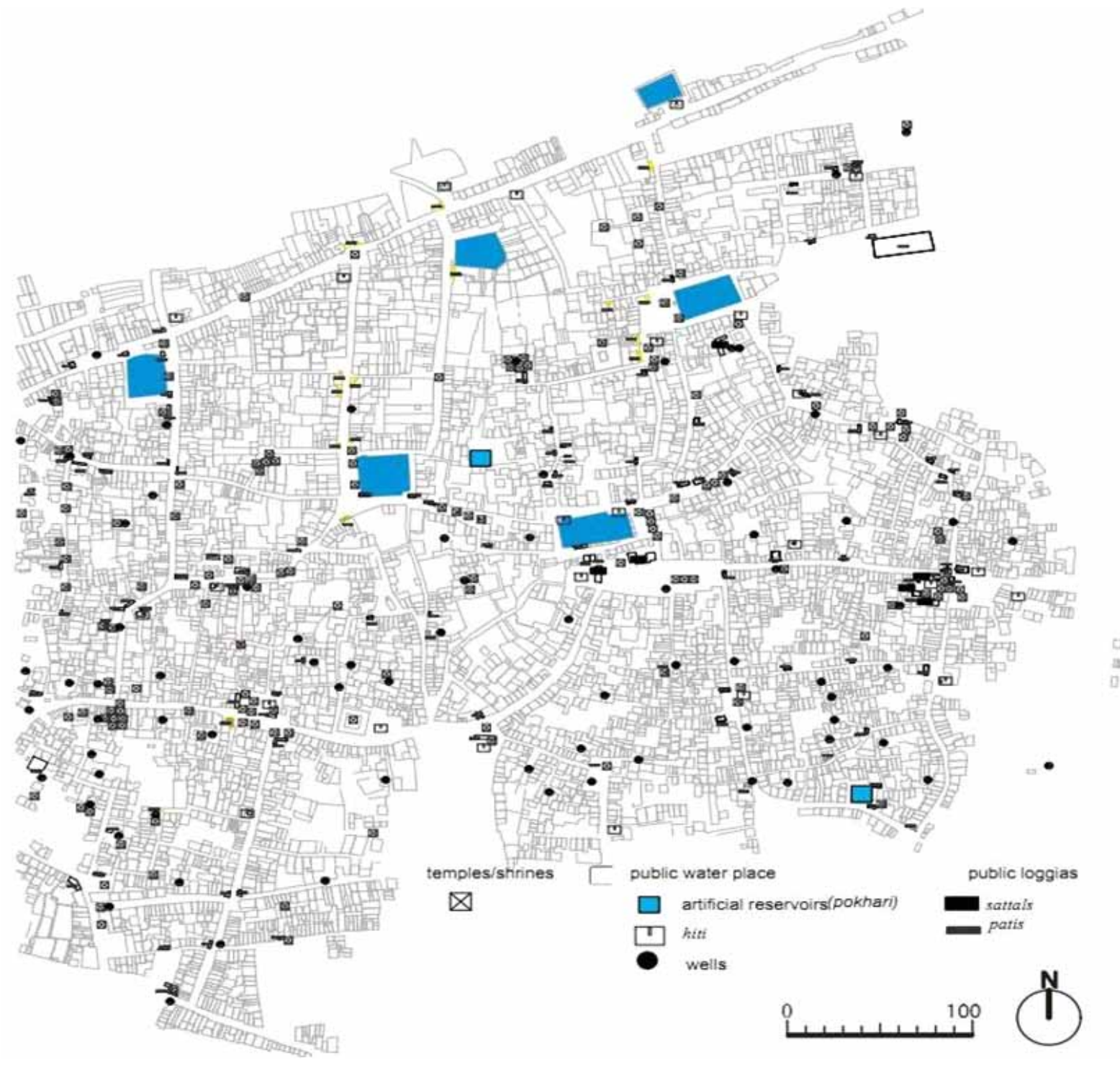

Fig.3. Distribution of the Urban Facilities

of urban tissue. Pant lays special emphasis on Ganesa shrine and kshetrapala to grasp the subdivision of urban structure that is linked to neighborhood community and clan community. Both of his research works are essential foundation to move forward in this field of research of urban tissue studies.

\section{Space Syntax and Structure of Bhaktapur}

Space Syntax (SS) is a tool based on the graph theory to identify topological entity of space, where people are supposed to gather easily in a manner like the flow of stream towards a river. There are several means of conducting spatial analysis under the concept of Spatial syntax. The paper adopts
Axial Line Analysis (ALA) among others, which is considered to be the most appropriate for the analysis of urban space².

Houses in Bhaktapur usually have a courtyard through which each household's entrance door is connected to the streets and lanes outside. There even exist networks of connected courtyards within an urban block. Fig 1 shows the idea of classification for outdoor community space in and around the dwellings, as well as typical public space such as squares, crossings and streets.

No.1 in Fig 1 is normally a backyard of a private residence with highly private character. Here such 
spaces (No. 2 to No. 9) excluding No.1 will be the subjects for SS analysis and defined as 'public space'. The light grey color in Fig 2 shows the network of public space drawn from our field survey based on 1985 cadastral map.

The result of ALA is also shown in Fig 2 by overlaying the lines with various 'Integration Values'3 indicated by different thickness. The streets of western and eastern part of the town exhibit different patterns. In western part, the single main artery running east-west and the lanes connected to it shows the highest value. On the other hand, there seems no dominant street in eastern part. This suggests that eastern part is not centered on a particular public space. Instead, eastern part is composed of several minor centers scattered within the built up area. Therefore, western part of the city assumes centralized spatial structure and eastern part a decentralized or multi-centered one. The result coincides with the familiar history that city of Bhaktapur had its origin in eastern part (where former palace existed) and cities developed from dispersed settlements merging into a single entity in the course of time.

The difference between the east and west of the city is partly evident in the street patterns. In western part, streets and lanes are running more or less straight and crossings have right-angled corners (a lane can be considered to extend beyond the crossing). According to the calculation procedure of ALA, it is true that a straight long path tends to acquire high 'Integration Value'. This explains why ALA generated high Integration Value along and around main artery in the west. Meanwhile streets and lanes found in eastern part are winding gently. Their width is not uniform creating alcoves at some points. Streets do not always cross at right angle at crossings which are very often expanded to the extent that can be called as small squares. A street or a lane showing high Integration Value in eastern part generally starts from or ends at such small squares. That is to say squares are well connected and integrated in the settlement tissue of surrounding environment, reaching even to adjacent square in some instances.
The processional route of a portable shrine, observed on 23 ${ }^{\text {rd }}$ September 2010, as a sequence of Dasain Festival, is also shown in Fig 2. The procession only passed through Royal Square (Durbar Square) in western part. But it passed all the streets/lanes that ALA marked high Integration Value at eastern part. On the premise that festivals and processions should take place along routes and at points with prominent public character, we would say that the result of SS analysis matches the actual usage of urban space. This fact suggests the effectiveness of SS applied to the analysis on urban structure of Bhaktapur. The result of SS analysis might also support the hypothesis that independent early hamlets possibly merged into a town settlement. Thus, the present paper will take eastern part as a case study for further examination on the structure of the city.

\section{Distribution of Urban Facilities}

In the public space of Bhaktapur, many Hindu and Buddhist temples and shrines are located where people offer a morning prayer called puja. There are also several kinds of water source such as artificial reservoirs called pukhu (nepali: pokhari), public water place called hiti fed by water pipes running underground, and wells. Normally sufficient light is not available inside the houses, so, with the agreeable climate of the Valley people prefer to stay outdoors at public loggias called pati most of the time the year round. These urban facilities are deeply rooted in town people's daily life and activities.

Fig 3 shows the disposition of the abovementioned urban facilities in eastern part of Bhaktapur. Temples/small shrines are placed in the squares or in the wide alcoves of the streets and crossings. They are scarcely found within the street blocks. In most cases reservoirs are found in the northern half especially in the peripheral parts of the built up area. This is because of topographic feature of the city where northern half is generally higher than the southern half. Storing water in higher position helps to supply water to hitis from which people draw water for daily use. Hitis are usually located in places of public nature, most likely either 


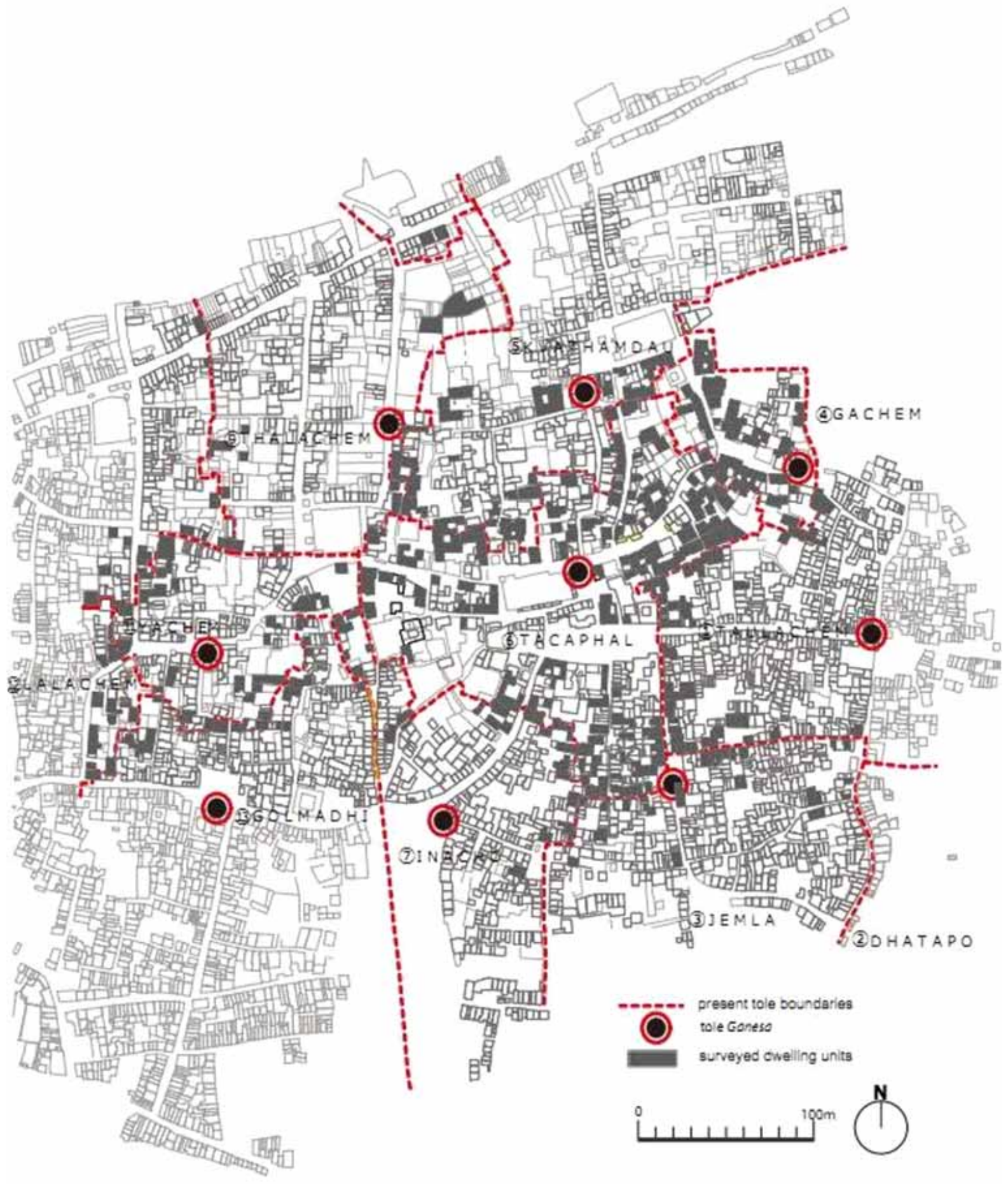

Fig.4. Tole boundary and location of Tole Ganesa

in larger squares or in places close to squares. They are also placed next to temples and shrines so that they provide worshippers holy water for puja offering. Wells are found in following three locations: 1) squares in a manner similar to hiti, 2) in the wide alcove space along streets or small squares, and 3) in the courtyard or backyard of private houses.

The locations of wells are accordingly related to the type of user community. Type 1) encompasses a wide range of people, open to public; Type 2) has 
residential dwellings around as its users and Type 3) is related to those particular households that have individual ownership of the well. In general, wells seem to have been dug for smaller communal groups as the demand of water became greater in the course of time.

There are two types of public loggias, namely, sattals for pilgrims and priests to stay, and patis for ordinary people to rest. Sattals stand within the squares directly connected to the main artery. Patis are rather widely spread from main streets and squares to corners of minor lanes. People not only take a rest there but also use as a stage for the musical performance of festivals, workspace for farm work, spinning, and place for housework, such as washing. Urban facilities of public use are found around important squares in each tole. Squares are the center of daily activities in eastern part of Bhaktapur.

\section{Tole Boundaries}

Pant (2000) discusses that the shrine of Ganesa is one of the essential elements constituting spatial structure of a tole. Fig 4 shows locations of the tole Ganesa in each tole. The boundaries dividing adjacent toles are also drawn in the same figure. The boundary data was collected by conducting interviews directly to the houses aligning with tole boundaries. Each tole has one tole-Ganesa in one of the major square of the tole. Gustschow (1975) suggests distinction between primary squares and secondary ones and the network between them. Fig 5 is the diagram showing the location patterns of tole Ganesa within the network of primary and secondary squares of the toles. Tole-Ganesa is generally found in a primary square. However, exceptional cases are seen in Gachen (No.4) and in Tachapal (No.6) where tole Ganesa temple/shrine is placed in the secondary square. There is a temple of Gachen Narayan in Gachen and Dattatraya, one of the monumental shrines in Bhaktapur, is in Tachapal. Both of these deities belong to larger community of the town. Yet, we can still see that tole-Ganesas stand close to primary squares both in Gachen and Tachapal.
We have already seen that urban facilities for religious and daily activities concentrate in squares. Thus, we can conclude that tole Ganesa along with other important urban facilities constitutes a primary square in tole. Tole boundaries coincide with streets in some cases (hereunder referred as 'boundary street') while it may not be so in other instances as shown in Fig 4 and Fig 6. ${ }^{4}$ Type 1 has tole boundary along the back to back plot division line.

We call this situation as 'back to back boundary division' as opposed to 'Boundary Street'. Type 2 has a tole boundary street, along which many courtyard buildings stand.

Earlier, residents in a single courtyard building must have been closely related by blood relation. But nowadays, each dwelling unit surrounding a courtyard does not always belong to the same extended family. Probably this happened in the course of time due to densification of the settlement and modernization. Therefore, in this paper, we do not call Type 2 a courtyard house but 'courtyard dwelling units', to imply that the courtyard consists of separate household units collectively forming the shape of a courtyard house. However, dwelling units surrounding a courtyard (Fig 6: Type 2) is most likely supposed to maintain stronger ties among neighboring units than with the dwelling units on the opposite side of the street. This would explain why a tole boundary street is found along the side of courtyard dwelling units.

Type 2 can be subdivided into two categories by the primary access pattern to the courtyard. Type 2-1 can be described as courtyard dwelling units with direct access to the tole boundary street. So can be Type 2-2 as courtyard dwelling units without direct access to the tole boundary street.

\section{Daily Activities Taking Place in Public Space 6.1 The Shrine of Ganesa}

In Kathmandu Valley towns, Ganesa is considered to be the guardian god of a community. A morning visit (puja) is obligatory to the shrine early in the morning around half past four in Bhaktapur. Fig 7 


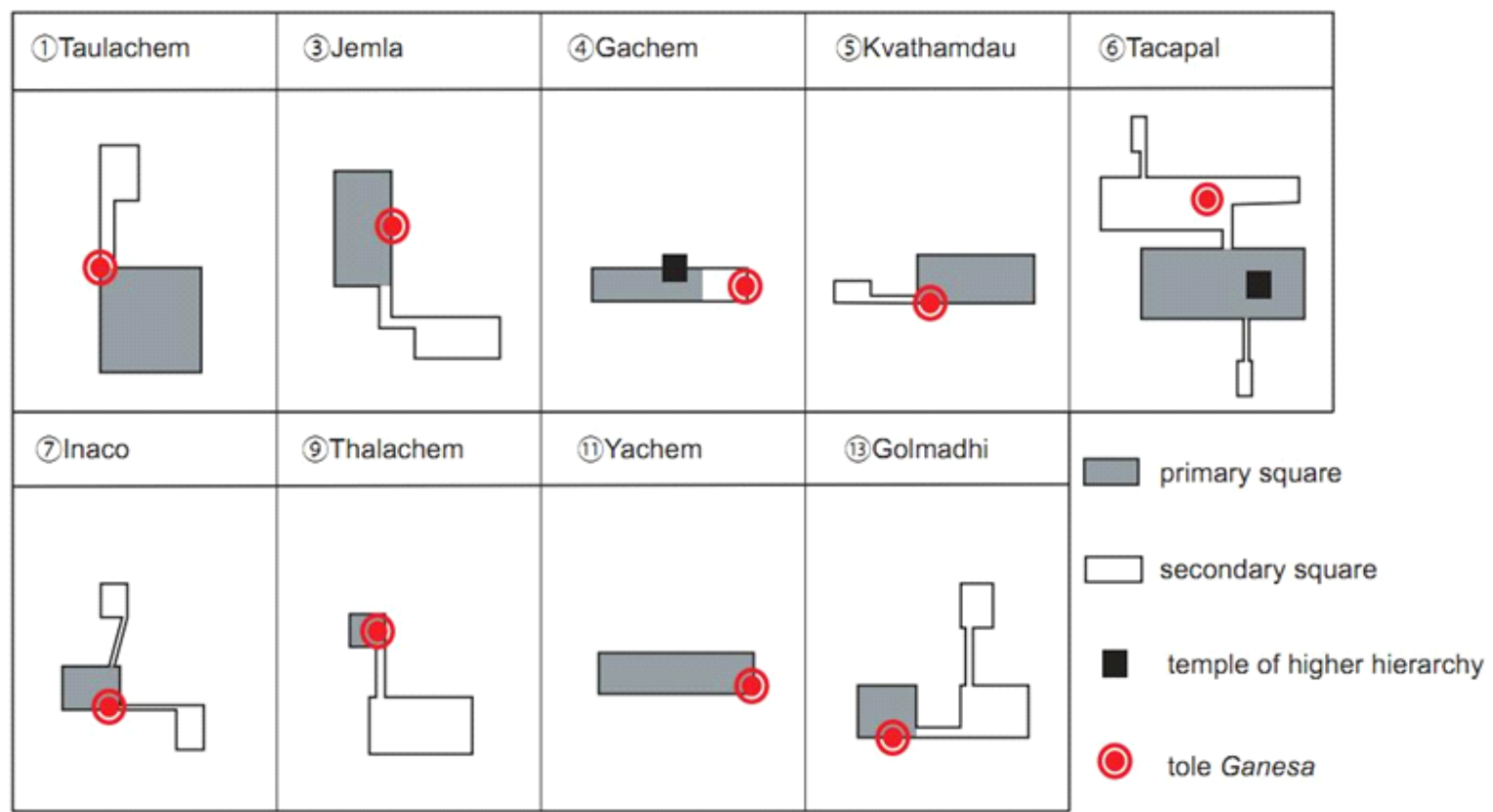

Fig.5. Network of squares and position of Tole Ganesa

tole boundary $\neq$ street

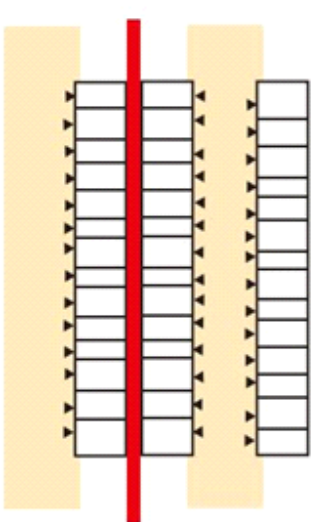

Type1

Dwelling units with back to back plot division line as $t o l$ boundary

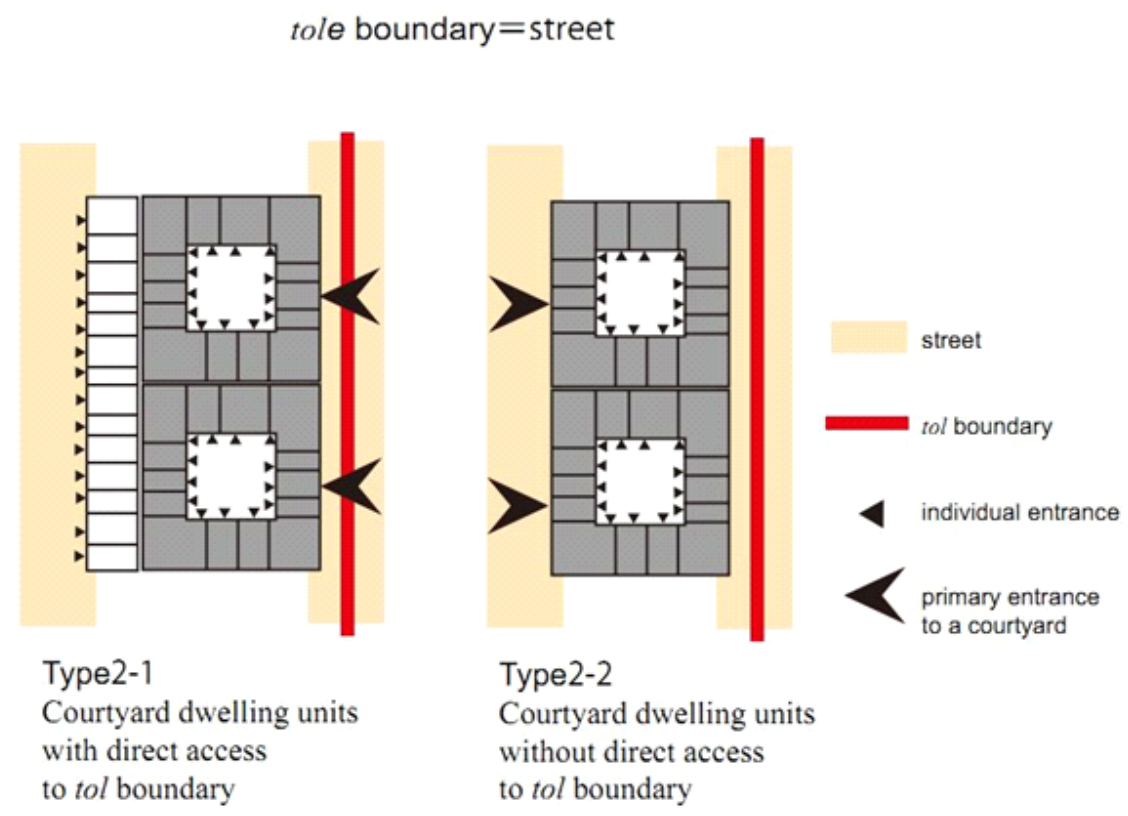

Fig.6. Types of urban tissue and Tole boundary 
shows positions of Ganesa temple/shrines and distribution of dwelling units belonging to the votary of respective Ganesa. Those who belong to the same tole offer worship to its tole Ganesa in general. But the worshipers' ranges numbered 6, 7 and 8 go to the one other than tole Ganesa. Such Ganesa shrine is called 'puja-Ganesa'. This fact tells us that several smaller religious communities do exist within a tole. While in cluster-6 several courtyard dwelling units form a religious community serving for their puja-Ganesa, in cluster-1 (tole Ganesa of Tachapal) and cluster-3 (tole Ganesa of Jenla) some units (note that these are not courtyard dwelling units) cross tole boundaries for worshiping the Ganesa other than the tole Ganesa within the tole. In cluster-1, there are dwelling units from Taulachem that visit to tole Ganesa of Tachapal. This could have something to do with the greater significance of the Ganesa in Tachapal because of its central location at the eastern part of the city. In cluster-3, residents from a number of linear dwelling units, both from Taulachem and Tachapal, visit the tole Ganesa of Jenla. This happens probably because of its close distance.

The movements of the residents in visiting the Ganesa shrine across their tole boundary suggest the existence of dual form of dwelling clustersthe courtyard dwelling units and linear dwelling units in the urban structure as well as a dynamics in the shifting of tole boundaries in course of time.

\subsection{Public Water Place-Hiti, and Pati}

There appears a gender difference in the users of public water places (hitis) and public loggias (patis). Hiti supplies water for housework and daily life. Therefore, it is normally used by female members. Pati offers resting place to hang around in the public space besides other specific purposes, and is used normally by male members. Squares and crossings are always equipped with both hiti and pati. Thus, respective open spaces will be taken into consideration hereunder. The survey data are of squares and crossings as shown in Fig 8: a1 (Tachapal), a2 (Sakolan), a3 (Gachen), a4 (Jenla) and a6 (Kvathandu), a7 (Mokogali), a8 and a9.
Fig 9 shows type and extent of overlapping of user community of hiti and pati located in these squares. The overlapping relationships are categorized into four patterns as follows:

1) User community of both hiti and pati spread over the whole tract of tole. This is in square (a1), which is the central square of the tole and extensively open to public.

2) A complete overlapping of user community of both hiti and pati. This is the case of a8. It is to be noted that all the dwelling units belonging to a8 belong to the same tole Ganesa (No. 3 in Fig 9).

3) User community of hiti and pati are totally different. This situation is in a7 though both user groups belong to the same Ganesa (No. 6 in Fig 7). Residents take water from hiti nearby at the crossing of Mokogali but do not utilize pati located at the same crossing. They prefer to go to several different patis nearby other than of from a7 at the crossing of Mokogali. It is of interest that the Courtyard dwelling units near the square have their primary entrance facing the street. The residents must walk along the street before reaching the Mokogalli crossing. Passing through a public street may reduce the feeling of solidarity of the community.

4) User community of either facility is inclusive of that of the other (a2, a3, a4, a6 and a9). Users' extent of hiti is generally inclusive of that of pati except the case of a3. Therefore we understand that user community of pati, mostly men, is more or less limited to those who live nearby the facility. On the other hand, users of public water place, generally women, must walk out further distance for washing or fetching water.

Although we still need comprehensive data for users' extent related to respective community facilities, distribution of users' extent of hiti and pati, generally, seems smaller than the extent of community belonging to tole Ganesa or pujaGanesa. It is certain that a tole is subdivided into smaller community groups with regard to such daily activities. When we consider drawing water from 

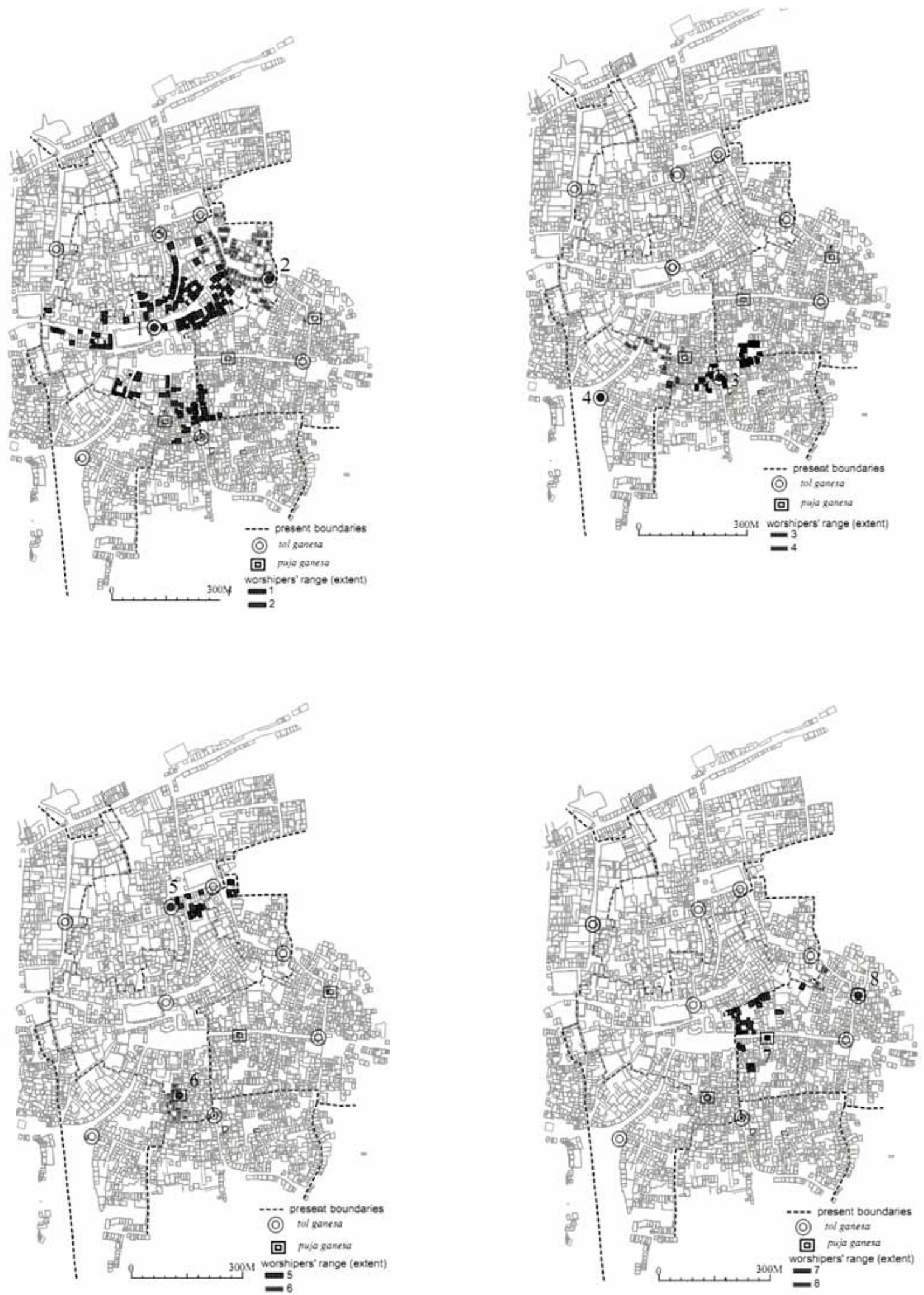

Fig.7. Location of Ganesa temples/shrines and their respective votaries 
public water place as a daily necessary activity, the users' extent of hiti appears to form steadily subdivided community groups under a tole compared to that of pati.

\subsection{Kshetrapala and Residential Units}

Kshetrapala is a small stone slab shaped and carved in a lotus flower motif, and is placed in front of the main door on the ground of streets and alleys. Lotus flower is acommon icon in both Hinduism and Buddhism. It is a symbol for god's pedestal and, in Sanskrit, kshetrapala means 'the protector of the field'. In common Newari usage, it is called 'pikha-lakhu-dyo', which literally means 'the deity of the area outside the house' ${ }^{5}$. Thus, kshetrapala is considered to be a guardian of a certain territory. Dwelling units in a row aligning with a street usually have their individual kshetrapala in front of their main door facing the street. Our observation

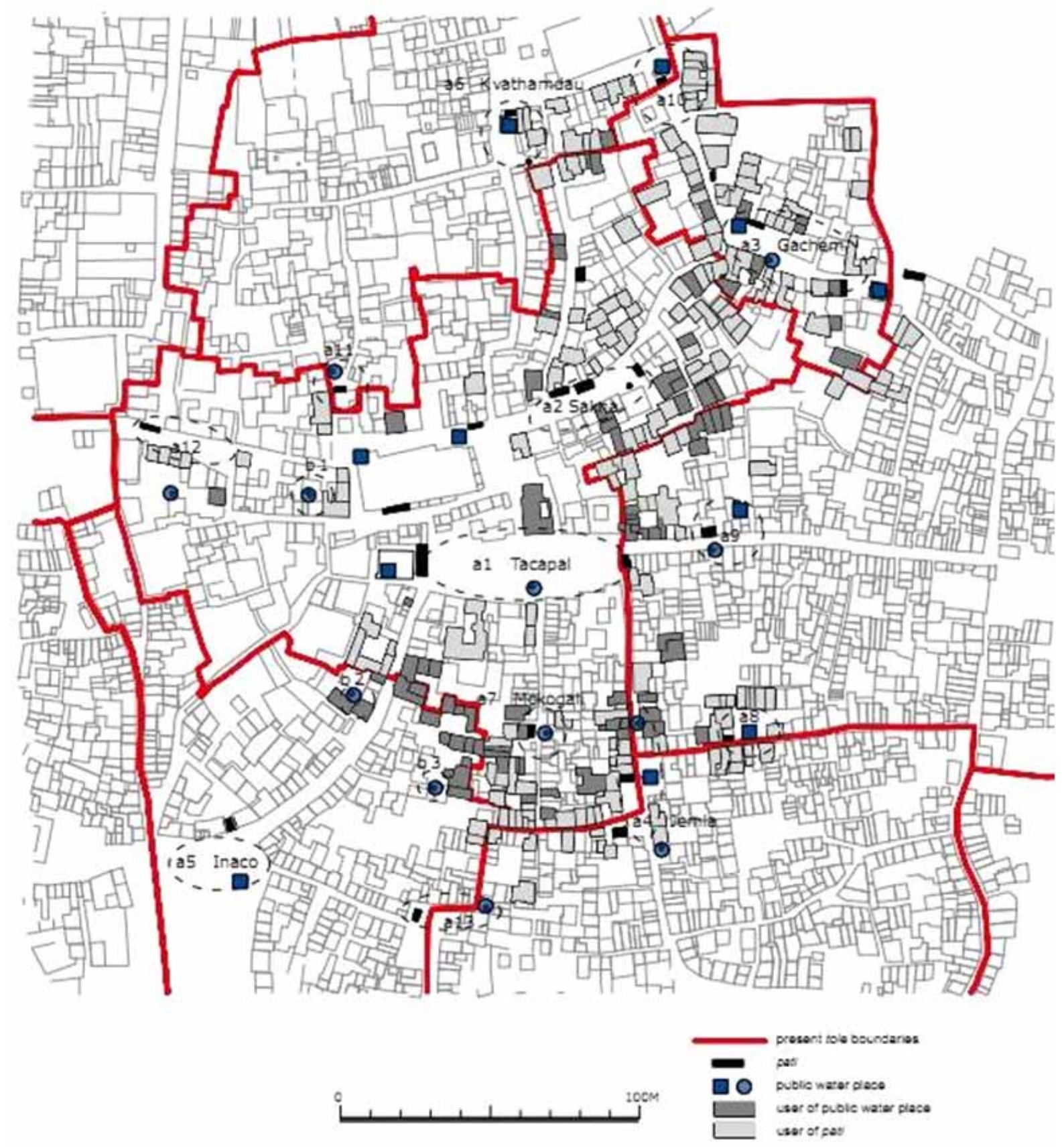

Fig.8. Public water places and patis at the eastern part of the city 


\begin{tabular}{|l|l|l|l|}
\hline a1 Tacapal & a2 Sakna & a3 Gachen & a4 Jemla \\
\hline & & & \\
\hline & & & \\
\hline & & & \\
\hline
\end{tabular}

users' extent of public water place

- public water place

users' extent of pathi

pathi

users' extent of both public water place and pathi

Fig.9. Overlapping patterns of user community of public water place and pati

coincides with the result of previous research that shows that such pattern has something to do with the latest development phase of dwelling clusters. There are cases that courtyard dwelling units have a single kshetrapala at the primary entrance into the courtyard or inside the courtyard. In such instances, it is the protector of the whole dwelling units around a courtyard, while in the former located at the primary entrance the kshetrapala would play the role of protection for all units inside the plot boundary. In other cases, dwelling units surrounding a small open space/square share a single kshetrapala at the entrance of which it is placed. Then it is basically a protector of the small open space/square. Relation between kshetrapala and dwelling units imply arious types of minimal communal units.

Based on the extensive mapping survey on kshetrapalas in various open space, Fig 10 proposes a typology of residential units ${ }^{6}$ and shows the distribution of classified residential unit types in the eastern part of Bhaktapur.

Preceding the courtyard dwelling units, there existed traditional monasteries, which also took 
the shape of courtyard building. ${ }^{7}$ At eastern part of Bhaktapur, the Hindu monasteries called math, serviced as residence to the priests. This residential unit is categorized as Type 0 ('Intact Courtyard House').
Residential unit Type 1 consists of two variations of 'Courtyard Dwelling Units'. Type 1-1 succeeds Type 0's spatial structure with a courtyard. But it is not inhabited by a family tied by a kinship anymore, and dwelling space found in Type 0 is divided into
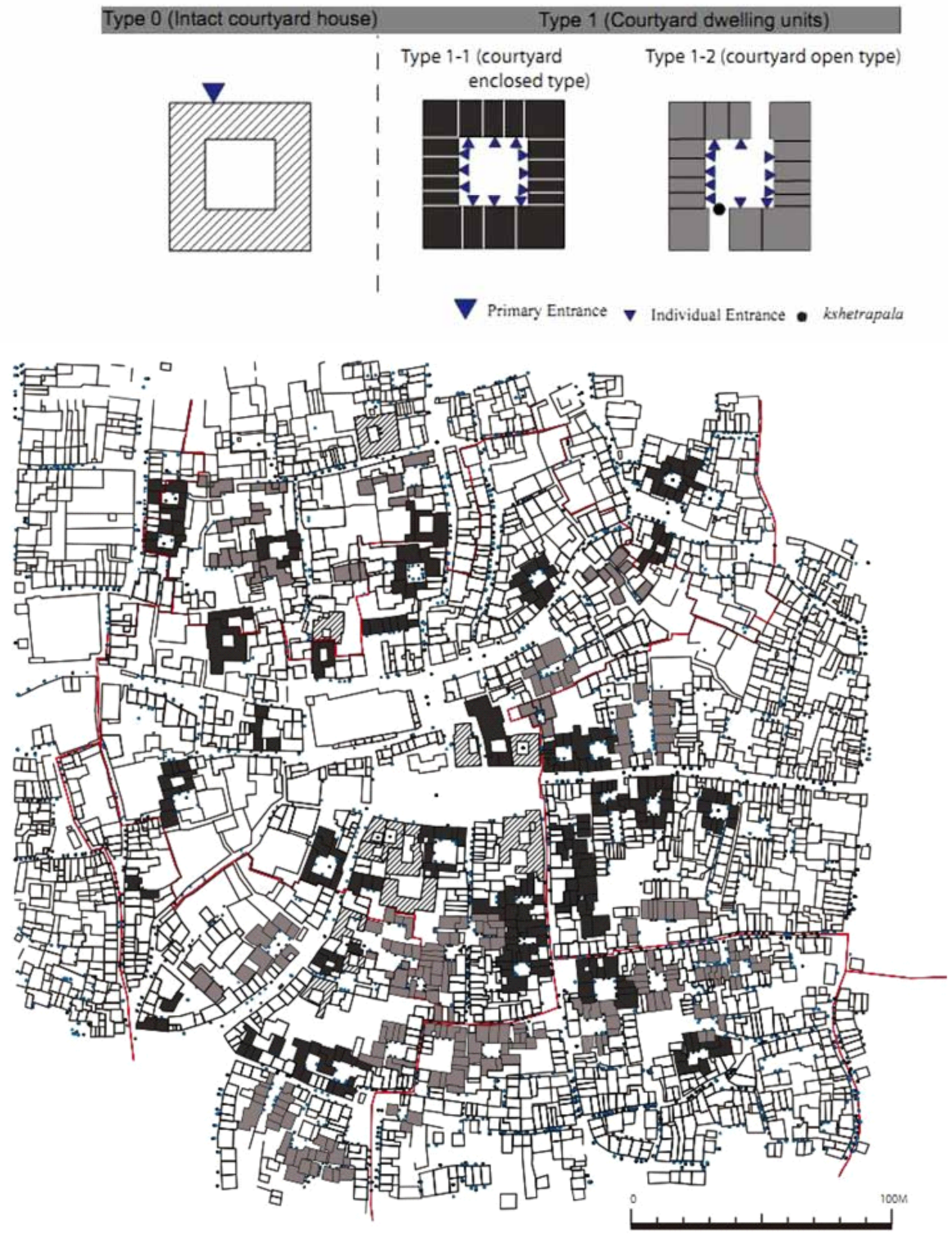

Fig.10. Types of residential unit model (above) and their distribution in eastern part of Bhaktapur (below) 
Type 2-1 (additional courtyard) 'Type 2-2 (linear extension type Type 2-3 (linear extension type

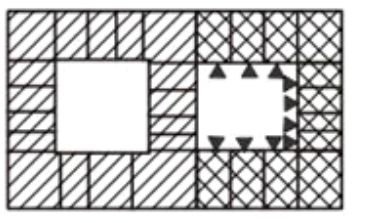

with khsetrapala)

without khsetrapala)
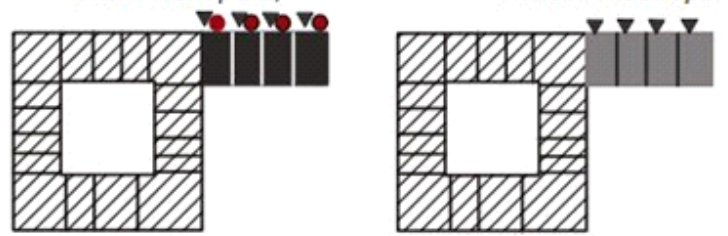

$\boldsymbol{\nabla}$ Individual Entrance $\bullet$ kshetrapala

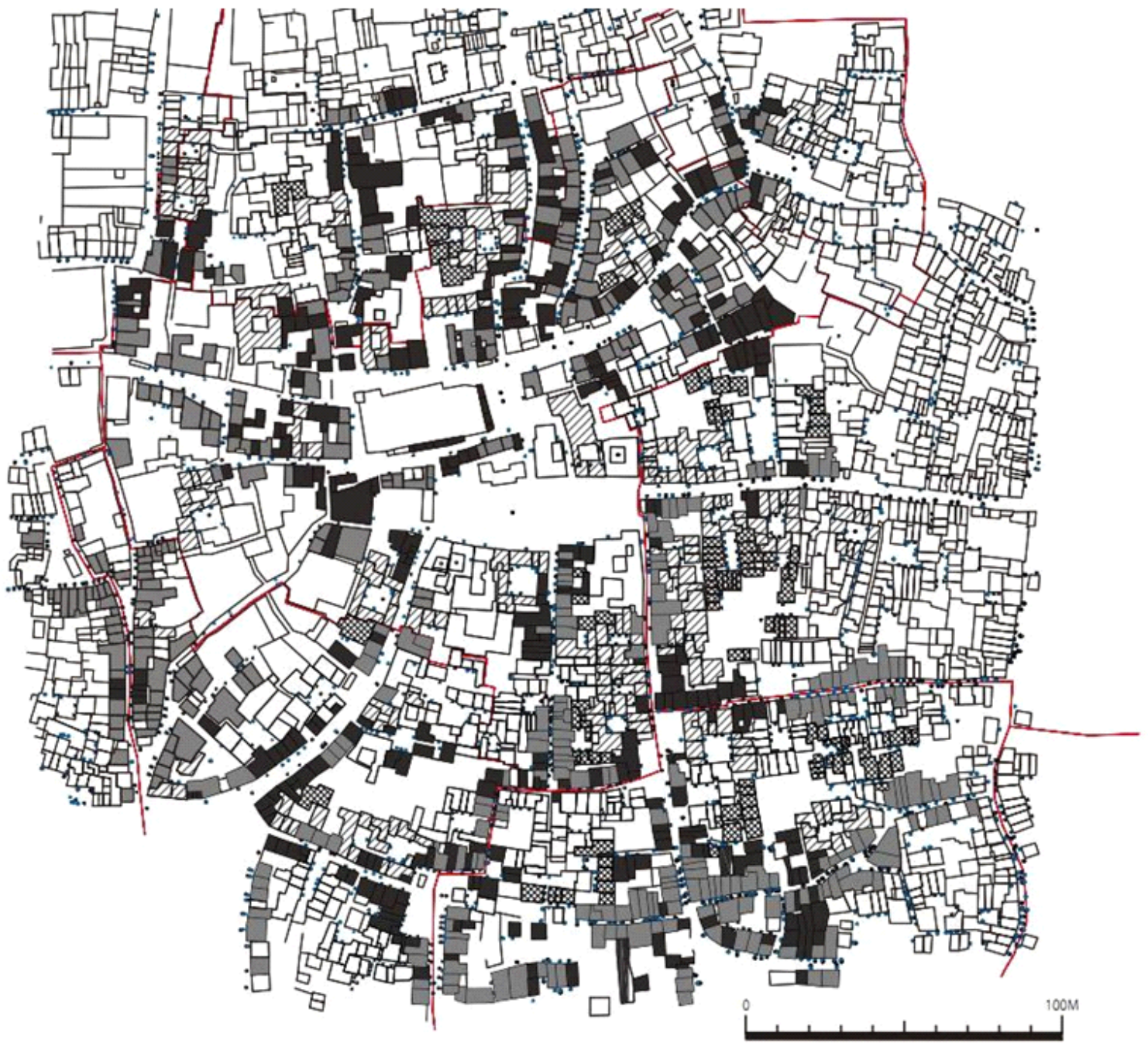

Fig.10. continued 
a number of dwelling units with individual access to the door. Thus we call Type 1-1 'courtyardenclosed type' under the category of courtyard dwelling units. On the other hand, Residential unit Type 1-2 forms partially opened courtyard. Thus Type 1-2 is called as 'courtyard-open type'. The actual formation process of Type 1 whether it is subdivided from an intact courtyard house or it gradually resulted in the shape of a courtyard/open space still needs further examination on its urban tissues. So far the classification is based on the present condition of the building and relative situation of kshetrapala. Residential unit Type 2 is of those dwelling clusters that were formed by the 'Extension of Dwelling Units'. It is further divided into three types. Type 2-1 is the courtyard dwelling units expanded to form a new courtyard. It is called 'Additional Courtyard Type'. Dwelling units when extended in a linear fashion belong to Type 2-2 called 'Linear Extension Type with kshetrapala' and, Type 2-3 is 'Linear Extension Type without kshetrapala'.

The distribution of residential unit types along squares provides us insight into the development of urban forms of Bhaktapur in temporal and geographical dimensions. For instance, Dattatraya Tachapal (a1), where Hindu trinity gods are enshrined, is surrounded by many residential units of Type 0 .

Jenla (a4), Inacho (a5) and square at a13 are surrounded by residential unit of Type 2. In these three places, squares or alcoved crossings are bordered by the extensions of linear dwelling units. The interior parts of the urban blocks are occupied by courtyard dwelling units with dwelling units of linear development types along the streets. On the supposition that existence of original courtyard dwelling units precedes that of linear extended ones (see Endnote 5), we may propose a hypothesis that present squares and alcoved crossing were gradually formed in the course of time as the densification of the settlement took place with the increase of population. This historical built up process along with the distribution of different types of residential unit shown in Fig 10 presents us with the image of double layered urban tissues in the important parts of the city.

\section{Conclusion}

This paper analyzed urban tissues of Bhaktapur with regard to the spatial structure of public space and community boundaries, which are subdivided or traversed by people's daily activities, such as, during the worship of Hindu shrines and utilization of public water places or, in the use of public loggias. Primary findings of this paper are summarized as follows:

i. The result of Spatial syntax analysis characterizes eastern part of Bhaktapur to exhibit decentralized or multi-centered spatial structure as opposed to the centralized one found in western part.

ii. In eastern part of Bhaktapur, indispensible urban facilities for people's daily activities are concentrated at important public space of the tole whose essential spatial elements, above all, consists of squares and Ganesa shrine.

iii. Our field survey revealed the present tole boundaries. The organization of urban tissue with respect to tole boundaries are categorized into three patterns as illustrated in Fig 6 that show close links to forms of dwelling cluster forms - courtyard or linear.

iv. Considering the morphology of tole boundaries, it appears that certain changes occurred in the boundary with the development of the dwelling cluster types such as courtyard form or linear form.

v. Basically the extent of a tole coincides with the religious community belonging to the Ganesa shrine. Yet there do exist cases where user community of Ganesa shrine, public water places and public loggias traverse across tole boundaries forming a different community around smaller squares or alcoved crossings equipped with such urban facilities. Such inconsistency seems to happen particularly where urban tissue includes courtyard dwelling units aligning with tole boundary street.

vi. Dispositions of kshetrapalas help us to discern patterns of residential units. Courtyard 
dwelling units tend to be located in the interior parts of urban blocks and they are surrounded by linear dwelling units. An urban block has double layered urban tissue between its interior and periphery.

In summary, the paper brought to light that urban tissue, especially courtyard dwelling unit, in eastern part of Bhaktapur, is deeply linked to various level of community units, and that the unit, along with the other elements of urban tissue, could be the key element to discern the urban formation process of Bhaktapur city.

\section{Acknowledgements}

The authors sincerely acknowledge the support provided by Khwopa Engineering College, Bhaktapur, in the course of this study of Bhaktapur including, in particular, the assistance from the Postgraduate Department of Urban Design and Conservation.

\section{References}

[1] Gutschow, N. and Kolver, B., 1975. Ordered Space Concepts and Functions in a Town of Nepal. Wiesbaden, F. Steiner Verlag.

[2] Scheibler, G., 1998. Building Today in a Historical Context-Bhaktapur, Nepal. Kathmandu: Ratna Pustak Bhandar.

[3] Pant, M. and Funo, S., 1998. Spatial Structure of a Buddhist Monastery Quarter of the City of Patan, Kathmandu Valley. J. Archit. Plann. Environ. Eng., AIJ, No.513, pp 183-189.

[4] Pant, M. and Funo, S., 2000. Spatial Structure of the Jyapu Community Quarters of the City of Patan, Kathmandu Valley. J. Archit. Plann. Environ. Eng., AIJ, No.527, pp 177184.

[5] Pant, M. and Funo, S., 2001. Analysis of Settlement Clusters and the Development of the Town of Thimi, Kathmandu Valley. J. Archit. Plann. Environ. Eng., AIJ, No.543, pp 177185.

[6] Gutschow, N., 1975. Functions of Squares in Bhaktapur, Kathmandu \& Patan.

[7] Levy, R. I., 1990. Mesocosm: Hinduism and the organization of a Traditional Newar City in Nepal. Berkley: University of California Press.
[8] Tiwari, S. R., 2009: Temples of the Nepal Valley. Kathmandu: Sthapit Press.

[9] Hillier, B. and Hanson, J., 1984. The Social Logic of Space. Great Britain: Cambridge University Press.

[10] Hillier, B., 1996. Space is Machine, Great Britain: Cambridge University Press.

\section{Endnotes}

[1] Tole is the traditional administrative and community unit. Despite the modern day subdivision in 'ward', tole units continue to preserve certain important aspects of people's daily activities as examined in this paper.

[2] For the basic introduction of Space Syntax theory, see Ref 9 and Ref 10 both by Hillier. In this paper authors utilized one of the SS software called 'Depth Map' that runs on Windows available at http;//www.spacesyntax.org

It should be also noted that in the analysis 'global' and 'local' levels are distinguished. This is defined by setting the value of 'radius'. Axial Line Analysis with radius 3 ( 2 in case of Depth Map) is analysis with local level and is supposed to be suitable for the analysis on historic pedestrian cities. On the other hand, global level analyses take all the entities around the target entity into the calculation. Suppose you can reach target entity from every single entity of the analyzed area, then you need moralization or transport means. So global level is to be adapted to modern city analysis.

[3] Int. $\mathrm{V}$ (Integration value) is derived from RA (Relative Asymmetry). RRA (Real Relative Asymmetry) is standardized value of RA. Int. V is defined as reciprocal of RRA.

RAi (Relative Asymmetry Value on a particular vertex i) is calculated as follows ( $k$ : total number of vertexes, : Mean Depth on vertex i).

$\mathrm{MD}_{\text {min }}=1, \quad \mathrm{MD}_{\text {max }}=k / 2$,

$\mathrm{RA}_{\mathrm{i}}=\left(\mathrm{MD}_{\mathrm{i}}-\mathrm{MD}_{\min }\right) /\left(\mathrm{MD}_{\max }-\mathrm{MD}_{\min }\right)=2\left(\mathrm{MD}_{\mathrm{i}}-1\right) /(k-2)$

$\mathrm{D}_{\mathbf{k}}$ as coefficient for standardization, Int. $\mathrm{V}$ is

$D_{k}=2\left[k\left\{\log _{2}\left(\frac{k+2}{3}\right)-1\right\}+1\right]$

$\mathrm{RRA}=\frac{\mathrm{RA}}{\mathrm{D}_{\mathrm{k}}}$

Int. $\mathrm{V}=\frac{1}{\mathrm{RRA}}$

The higher Int.V of a particular vertex (node in spatial structure) is, more easily people reach the vertex from the surrounding vertexes. The vertex with high Int. V can be described 'shallow'.

[4] It seems quite unusual for tole boundaries to coincide with streets when compared to the examples of community 
boundaries in Japanese traditional cities. Kyoto has survived as a capital city of Japan for more than 10 centuries. There community boundaries once set on the streets by the contemporary dynasty gradually shifted to backside of housing plots forming 'Ryogawa-cho' community (literally means bothsides community). In Ryogawa-cho, houses facing each other on both sides of a street finally came to belong to the same community. This seems quite natural when people always see each other over a street along which shophouses came to be built.

[5] For the detail explanation on kshetrapala and its significance, see Pant (2001).

[6] Here the expression 'residential unit' is distinguished from dwelling unit'. Dwelling unit means an independent house as a part of collective housing. Residential unit is described as this collective housing fundamentally incorporated in a continuous structure including extended part of dwelling units. Pant (2001) classifies residential clusters into three types following the dwelling cluster pattern with respect to kshetrapala. One of which is dwelling units clustered in linear pattern and each unit possessing a kshetrapala at the front door. This is considered the latest urban development that shows individuality of each dwelling unit.

[7] Pant (1998) in his study of Patan describes that the planned courtyard residential quarters followed the bahal type of Buddhist monasteries that were built in courtyard form. Buddhist monasteries for married Buddhist priests were known as 'bahal' different from Math for Hindu monks. 